Int. J. Dev. Biol. 61: 655-664 (2017)

doi: 10.1387/ijdb.170258jg

\title{
Origin and evolution of the chordate central nervous system: insights from amphioxus genoarchitecture
}

\author{
BEATRIZ ALBUIXECH-CRESPO ${ }^{1}$, CARLOS HERRERA-ÚBEDA ${ }^{1}$, GEMMA MARFANY ${ }^{1}$, MANUEL IRIMIA ${ }^{* 2,3}$ \\ and JORDI GARCIA-FERNÀNDEZ*,1
}

\begin{abstract}
${ }^{1}$ Dept. Genetics, Microbiology and Statistics and Institute of Biomedicine (IBUB), Faculty of Biology, University of Barcelona, ${ }^{2} E M B L / C R G$ Systems Biology Research Unit, Centre for Genomic Regulation (CRG), The Barcelona Institute for Science and Technology, Barcelona, Spain and ${ }^{3}$ Universitat Pompeu Fabra (UPF), Barcelona, Spain
\end{abstract}

\begin{abstract}
The vertebrate brain is arguably the most complex anatomical and functional structure in nature. During embryonic development, the central nervous system (CNS) undergoes a series of morphogenetic processes that eventually obscure the major axes of the early neural plate to our perception. Notwithstanding this complexity, the "genoarchitecture" of the developing neural tube brings into light homologous regions between brains of different vertebrate species, acting as a molecular barcode of each particular domain. Those homologous regions and their topological interrelations constitute the ancestral, deeply conserved, bauplan of the vertebrate brain. Remarkably, although simpler, the cephalochordate amphioxus shares multiple features of this bauplan, serving as a privileged reference point to understand the origins of the vertebrate brain. Here, we review the development of the chordate CNS in view of the latest morphological and genoarchitectonic data from amphioxus. This comparison reveals that the amphioxus CNS is far from simple and provides unique insights into the structure of the vertebrate CNS and its evolutionary origins. In particular, we summarize recent research in amphioxus and vertebrates that has challenged views on the major partitions of the vertebrate brain, proposing a novel organization of the chordate CNS bauplan that better reflects developmental and evolutionary data.
\end{abstract}

KEY WORDS: bauplan, brain partition, DiMes, vertebrate CNS, cephalochordate

\section{Introduction}

Homology is a fundamental concept in biology and one of the key pillars of comparative embryology. Therefore, it is not surprising that since its early years, Evo-Devo researchers have discussed whether anatomy or gene expression are better indicators of "strict" homology ("the same organ in different animals under every variety of form and function", Owen 1843, pp.379). These controversies started soon after developmental gene expression data from single genes were first compared between two species (e.g., Abouihef et al., 1997, Wray and Abouihef 1998), and still persist in the postgenomic era (Tschopp \& Tabin, 2016), when entire transcriptomes can be compared.

It is not surprising, then, that searching for homologies, divergences, and innovations in the most complex and fascinating structure in nature - the central nervous system (CNS) of vertebrates - has been, and surely will be, the subject of study from very different perspectives by many researchers. Currently, there are large amounts of gene expression data that can be used as topological markers in the developing vertebrate CNS. As all vertebrate neural tubes are homologous and develop under similar principles, it is generally assumed that gene expression patterns, which provide positional information and give insights into the specification and maintenance of brain derivatives, are, overall, good markers of homology (Morona et al., 2011, 2016). However, comparisons between vertebrate and non-vertebrate CNS are more challenging, as similarity of (relative) gene expression patterns are evaluated between highly diverse, and often quite dissimilar, anatomical structures, without a clear

Abbreviations used in this paper: $\mathrm{AP}$, anteroposterior; $\mathrm{ARCH}$, archencephalic protagma, CNS, central nervous system; DEU, deuteroencephalic protagma; DI, diencephalon; DiMes, DiMesenphalic primordium; MB, midbrain.

\footnotetext{
*Address correspondence to: Manuel Irimia. Centre for Genomic Regulation (CRG), Barcelona Institute of Science and Technology (BIST), Barcelona, Spain. E-mail: mirimia@gmail.com (iD) http://orcid.org/0000-0002-2179-2567 or

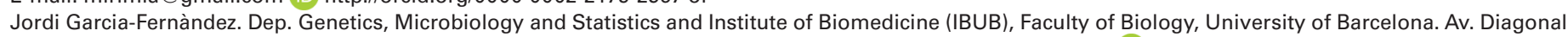
643, 08028 Barcelona, Spain. E-mail: jordigarcia@ub.edu - http://www.ub.edu/genetica/evo-devoen/garciare.htm (ID) http://orcid.org/0000-0001-5677-5970
} 
A

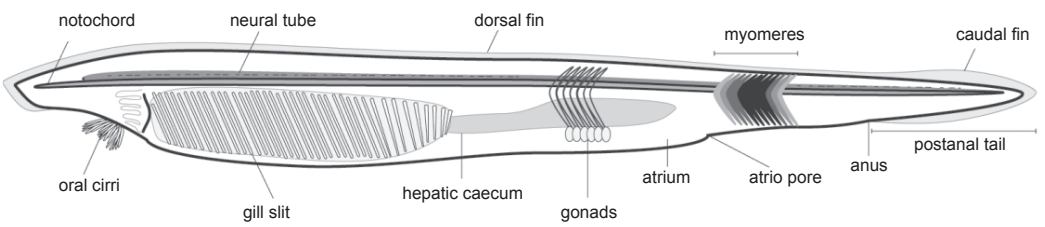

B

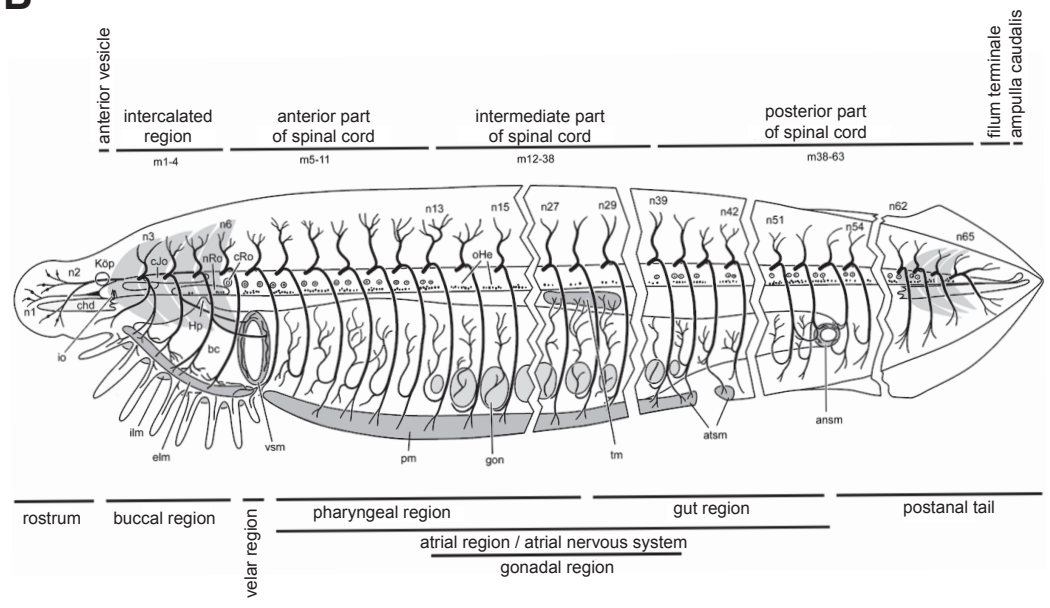

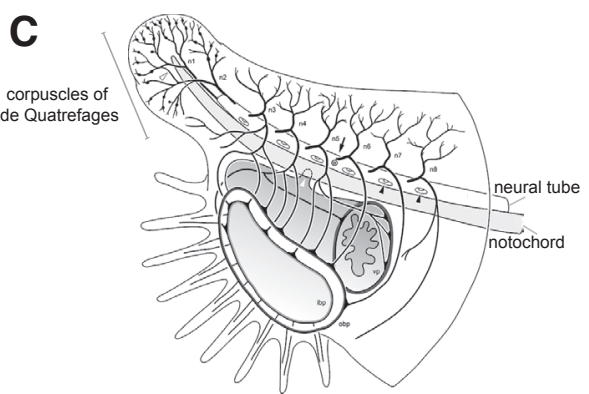

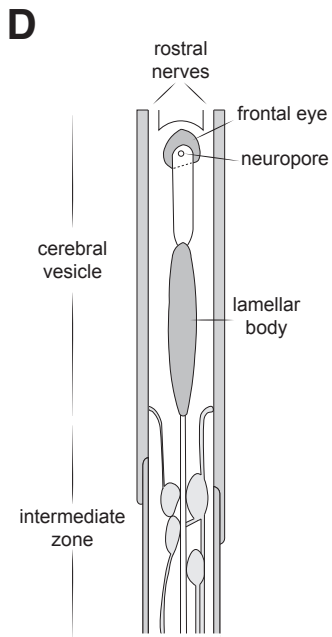

Fig. 1. Amphioxus anatomy and neural system. (A) Schematic representation of an adult amphioxus, indicating major anatomical structures. (B) Innervation of the adult amphioxus, dorsal nerves 1, 2, $3 \ldots(n 1, n 2, n 3 \ldots)$, infundibular organ (io), notochord (chd), Kölliker's pit (Köp), Joseph cells (c Jo), nucleus of Rohde (nRo), Rohde cell (cRo), Hatschek's pit (Hp), inner labial muscle (ilm), external labial muscle (elm), buccal cavity (bc), velar sphincter muscle (vsm), pterygeal muscle (pm), gonad (gon), organ of Hesse (oHe), trapezius muscle of atriocoelomic funnel (tm), atriopore sphincter muscle (atsm), anal sphincter muscle (ansm). (C) Detail of innervation in the most anterior tip, velar plexus (vp), inner buccal plexus (ibp), outer buccal plexus (obp), first cell of Rohde (arrow), Hatschek's pit (white arrowhead), anastomosis between nerves 1 and 2 (open arrowhead), two of the neuromuscular contact zones (black arrowheads). (D) Schematic representation of the neural tube (dorsal view, anterior is up). (B,C) Reproduced with slight modifications from Witch and Lacalli (2005, C 2008 Canadian Science Publishing or its licensors, reproduced with permission). (D) Adapted from Lacalli (1994). Anterior is to the right and dorsal is up in $(A, B, C)$.

homologous topological reference. Hence, the study of amphioxus, which has a centralized CNS that develops from a neural plate that is unambiguously homologous to that of vertebrates, has been particularly useful to shed light into how the CNS of vertebrates has originated and evolved.

Here, after an introduction to the key phylogenetic position of the amphioxus in the path to vertebrates, we review classic and recent studies on vertebrates and cephalochordates to provide a comparative view of the development and morphology of their CNS. We begin by setting the conceptual framework of our comparisons: comparative neuroanatomy and the prosomeric model. We will then review recent results suggesting a novel ontogenetic organization of vertebrate brain regions as inferred from comparative studies with amphioxus, and, finally, we will discuss the impact of this organization on our understanding of key adult brain structures in cephalochordates. The amphioxus: key to understanding chordate and
vertebrate transitions

For centuries, amphioxus has attracted the attention of zoologists, embryologists and, since 1980's, also of molecular biologists. First described by Peter Simon Pallas as a molluscan slug in 1774 (Pallas, 1774), later classified as a close relative of agnathan vertebrates, hagfish and lampreys (Costa, 1834), its phylogenetically privileged position is now thought to be that of being the most basal-branching extant chordate (Delsuc et al., 2006). In this Special Issue of the Int. J. Dev. Biol., readers can learn about the fascinating quest of several research groups to collect, get to reproducing in captivity, and work with amphioxus embryos, first using large amounts of radioactive ${ }^{32} \mathrm{P}$ probes, then performing many PCRs, and from struggling for genome sequencing funding to, of late, trying all available and possible gene modification protocols (see Holland, this issue).

Cephalochordates share the chordate phylum with the Olfactores (Urochordata and Vertebrata) (Delsuc et al., 2006), with an estimated time of divergence from the last common ancestor at around 550 million years ago (Blair and Hedges, 2005; Delsuc et al., 2008). The main characteristic of chordates is the presence of a notochord, which extends along much of the body; in the particular case of cephalochordates, the notochord seems to extend beyond the most anterior tip of the neural tube (Fig. 1A), although this anterior-most part has been suggested to be homologous to the 
prechordal plate (see below). The very name of amphioxus is in fact an allegory of its shape (amphis = both, oxys = sharp). Unlike vertebrates, the amphioxus notochord is maintained throughout life and is the only skeletal structure present in the adult body. The hollow neural tube, which is dorsal to the notochord, is another of the morphological characteristics shared with vertebrates, in addition to the gill slits in the pharynx, the myomeres (or segmental muscle "bricks"), and the post-anal tail (Garcia-Fernàndez and Benito-Gutiérrez, 2009)

Not only has its prototypical body plan (bauplan) and phylogenetic position enticed evolutionary biologists, but also its genome is highly remarkable. One of the first genes cloned in amphioxus (Holland et al., 1992) supported the notion that the amphioxus had a prototypical genome with respect to the vertebrate - namely human - genome. In 1994, after the cloning of the single amphioxus Hox gene cluster (Garcia-Fernàndez and Holland, 1994), Peter Holland together with one of the co-authors here (back when they were both very young) and other colleagues, proposed that the origin of vertebrates was linked to the double duplication of an ancestral genome that was very similar to the present amphioxus genome, the so-called 2R hypothesis (Holland et al., 1994). Susumu Ohno already noticed the potential of gene duplication in evolution years before, based on earlier measures of genome size, and even proposed than the genome was duplicated somewhere in the path to vertebrates (Ohno, 1970). But it was not until 2005, with the publication of the first urochordate genome (Dehal and Boore, 2005), and definitely in 2008, with the publication of the amphioxus genome sequence draft (Putman et al., 2008), that this hypothesis was corroborated: about $95 \%$ of the human genome could be traced back to a double polyploidisation of an amphioxus-like genome. In these 14 years, the idea that those new genes were instrumental to the morphological innovations of vertebrates shifted subtly from emphasizing additional protein-coding sequences to the relevance of duplication and innovation of regulatory sequences, through the Duplication, Degeneration, and Complementation model (the DDC model, Force et al., 1999), or the Duplication, Degeneration, and Innovation model of regulatory DNA (the DDI model, Jiménez-Delgado et al., 2009). More recently, the link between genome duplication and epigenetic changes (Acemel et al., 2016) also supports the view that the 2R events at the origin and early evolution of vertebrates were instrumental to the path that led to us, humans.

In this review, we will show how amphioxus has also illuminated the origin and evolution of the vertebrate CNS, arguably the most paramount and defining organ of our clade.

\section{Conceptual framework: the prosomeric model}

A major breakthrough in our understanding of the bauplan of vertebrate CNS came with the publication of the prosomeric model by Puelles and Rubenstein (Puelles and Rubenstein, 1993;Puelles, 1995; Puelles,
2010; Puelles and Rubenstein, 2015). This model proposes that the vertebrate CNS is composed of basic units of neural development, the neuromeres, whose organizational principles are identifiable in the longitudinal and transversal axes across all studied vertebrate species (Fig. 2 B-B"). The prosomeric model facilitates comparisons across vertebrate species, since neuromeres refer to the 'intrinsic' axes, as established in the early neural plate, instead of the 'extrinsic' axes that had been used in other neuroanatomic approximations (Kuhlenbeck, 1967; Puelles and Rubenstein, 1993), and which are greatly affected by the complex morphogenetic events undergone by the neural tube upon closure (Fig. 2).

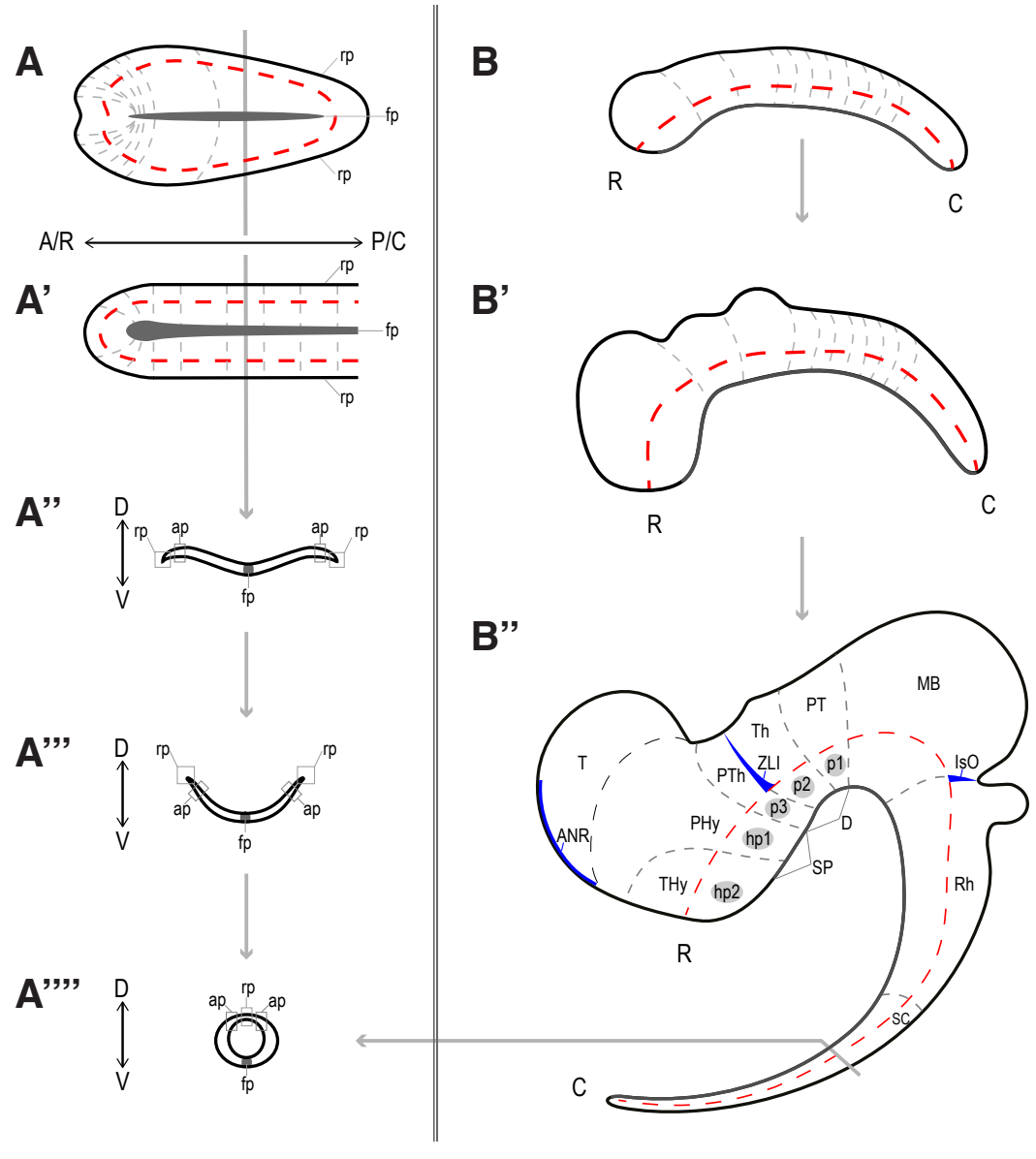

Fig. 2. Chordate neurulation and vertebrate central nervous system development. The vertebrate (A) and amphioxus ( $\left.\mathbf{A}^{\prime}\right)$ neural plate (dorsal view) fold ( $\left.\mathbf{A}^{\prime \prime}, \mathbf{A}^{\prime \prime \prime}\right)$ to form the neural tube ( $\left.\mathbf{A}^{\prime \prime \prime \prime}\right)$ similarly, generating a hollow nerve tube that closes dorsally by the roofplate (rp). (B) Schematic lateral views of bending of the vertebrate neural tube as a result of differential growth, resulting in an arching of its internal axis (red dotted line). Some neuromeres are indicated as the regionalization of the neural tube proceeds (grey dotted lines). The forebrain is subdivided into secondary prosencephalon (SP) with peduncular and terminal prosomeres (hp1 and hp2, respectively), which include the hypothalamic region, telencephalon $(T)$, and the optic vesicles, and Diencephalon $(D)$, with prosomeres 1, 2, and 3 (p1-p3), which are represented by the pretectum (PT), thalamus (Th), and prethalamus (PTh), respectively. More caudally, midbrain (MB), romboencephalon(Rh), and spinal cord (SC) regions are identified (for simplicity, their respective neuromeric components are not depicted). The position of the secondary organizers zona limitans intrathalamica (ZLI) and the isthmic organizer (ISO) are represented by blue spikes. Lateral view. Dark grey represents floorplate (fp) in all schemes; terminal hypothalamic prosomere (Thy), peduncular hypothalamic prosomere (PHy). A/R, anterior/rostral; $P / C$, posterior/caudal; D, dorsal; V, ventral. Adapted from Albuixech-Crespo et al., (2017). 
These primary axes are easy to identify in the early neural plate (Fig. 2A). The anteroposterior (AP) axis overlaps the longitudinal axis, whereas the mediolateral axis will correspond to the dorsoventral (DV) axis after neural tube closure, in which the neural plate midline and border will become the neural tube floor and roof, respectively. Interestingly, this layout results in an anatomical singularity in the neural plate, since the presumptive basal (ventral) plate, alar (dorsal) plate and roof run concentrically across the floor in the anterior and posterior tips of the neural plate (Fig. 2A, B-B'). As development progresses, the AP axis bends due to the differential growth of different territories of the neural tube (Fig. 2 B-B"). Despite this bending, each neuromere is established according to its position with respect to the AP axis (Fig. 2B). Moreover, the DV axis maintains its orthogonal relationship with the AP axis. Thus, the prosomeric model organically defines the basic developmental units of a tissue whose morphology is highly variable and plastic, assisting comparisons between neuroanatomies of equivalent bauplans (Puelles and Rubenstein, 1993; Puelles, 1995; Puelles and Rubenstein, 2015).

Moreover, an additional crucial aid for comparative neuroanatomy is provided by gene expression patterns. During the development of the CNS, different populations of neural progenitors are established based on their molecular codes. The pool of transcriptionally active genes is different for each particular group of cells, and the dynamics of these specification processes eventually result into positional identities in the neuroepithelium, what is known as neural patterning. This relationship between specific spatiotemporal gene expression patterns and the positional identity of the neural progenitors is the basis for the genoarchitecture. This concept has been exploited by Evo-Devo approaches, facilitating comparisons of developing vertebrate brains and allowing direct homology assignments (Ferran et al., 2007; Ferran et al., 2009; Medina et al., 2011; Puelles and Ferran, 2012). Similar approaches have also been undertaken to compare domains between more distantly related species. In particular, similarity of relative gene expression patterns along the AP axis have received much attention, reaching the conclusion that a subset of genes have likely maintained their relative AP positions since the last common ancestor of Bilateria (Lowe et al., 2003; Castro et al., 2006; Hirth, 2010; Irimia et al., 2010). However, as mentioned above, these inferences are often obscured by unavoidable problems encountered when comparing highly divergent CNSs.

\section{Secondary anteroposterior organizers: major players in vertebrate brain development and evolution}

The vertebrate CNS becomes regionalized along its AP axis very early in development. At the neural plate stage, expression patterns of genes such as Otx2, Gbx2, Fezf, Irx or Pax6 start establishing molecular subdivisions (Hidalgo-Sánchez et al., 2005; RodríguezSeguel et al., 2009). As development proceeds, the neural tube closes, bends, and the classical general AP subdivisions become morphologically apparent: the prosencephalon (which will be further subdivided into secondary prosencephalon and diencephalon), the midbrain, the rhombencephalon and the spinal cord. All these large AP domains will progressively regionalize and subdivide into neuromeres. For example, the rhombencephalon will metamerize into 11 rhombomeres (the neuromeres of the rhombencephalon), and the diencephalon into 3 prosomeres, with distinctive alar components: the prethalamus (p3), the thalamus (p2) and the pretectum ( $\mathrm{p} 1$ ), in a rostrocaudal order (Puelles and Rubenstein, 1993; Puelles, 1995) (Fig. 2).

Many of these subdivisions are orchestrated by the action of the secondary organizers (blue dashes in Fig. 2B'). An organizer is a cellular domain that releases particular regulatory morphogens that act upon its neighboring tissues. Three main secondary AP organizers have been described for vertebrates, the anterior neural ridge (ANR), located in the most rostral part of the neural tube; the zona limitans intrathalamica (ZLI), located between the prethalamus and the thalamus, and the isthmic organizer (IsO), which develops in the boundary between the midbrain and the rhombencephalon. Each of these organizers releases a specific combination of morphogens that influences the development of the surrounding structures. In particular, the ANR expresses Fgf8, which is essential for the correct regionalization of the prosencephalon and necessary for the correct formation of the telencephalon, a dorsal outgrowth of the secondary prosencehalon (Kiecker and Lumsden, 2012; Vieira et al., 2010). The reference morphogen in the ZLI is Shh, which is crucial for the differential specification of the thalamus (Crossley et al., 1996; Chi et al., 2003; Vieira et al., 2005; Hirata, 2006; Vue et al., 2009). Regarding the IsO, Fgf8 acts again as morphogen, but in this case together with Wnt 1 . This latter region can be identified from very early stages of development by the apposition of the expression patterns of Otx2 and Gbx2, which act antagonistically and are crucial to define the position and function of the IsO (Hidalgo-Sánchez et al., 2005; Kiecker and Lumsden, 2012).

Interestingly, the organizers and their associated genetic networks have been conserved since the origin of vertebrates (Osorio et al., 2005). However, the extent of evolutionary conservation is under debate when larger phylogenetic distances are considered, namely between vertebrates and other chordates or other deuterostomes (e.g. hemichordates). Several articles in recent years have discussed the presence/absence and homology/convergence of secondary organizers and their potential functionality as bona fide organizers (see Holland et al., 1997; Kozmik et al., 1999; Shimeld, 1999; Lowe et al., 2003; Takahashi and Holland, 2004; Lowe et al., 2006; Denes et al., 2007; Hirth, 2010; Steinmetz et al., 2011; Pani et al., 2012; Arendt et al., 2015; Yao et al., 2016, for engaging discussions and controversies). As expected, one of the clades at the center of these controversies is the cephalochordate amphioxus.

\section{The amphioxus CNS: challenging major subdivisions of the vertebrate brain}

The amphioxus CNS is composed of a neural tube placed dorsally to the notochord (Fig. 1). Rostrally, the notochord continues in appearance beyond the extension of the neural tube, although the anterior-most tip of the notochord has been proposed to be a homolog of the vertebrate prechordal plate (Albuixech-Crespo et al., 2017). A subtle widening in the anterior part of the neural tube, which corresponds to the cerebral vesicle, is barely noticeable in the adult, although this swelling is much more obvious at larval stages. Beyond this, there are neither anatomically recognizable neuromeres nor other morphological landmarks in the amphioxus neural tube to easily identify a segmental organization besides the visible dorsal nerves arranged in series (Fig. 1). However, examination at the histological and cellular level reveals visible 
histoarchitectonic differences in the AP and DV axes in larvae as well as in adults, which reflect differences or subdivisions between regions along the neural tube (Wicht and Lacalli, 2005) (Figs. 1 and 2; for detailed descriptions and cyto- and histo-architecture of the amphioxus nervous system, see Lacalli (this issue, and references therein)).
These differential histoarchitectonic arrangements imply that there must be a subjacent molecular regionalization of the amphioxus CNS. In fact, many genes involved in neural development in vertebrates are also expressed in cephalochordate neural development. Literature that describes, compares and establishes correspondences between expression patterns of genes involved

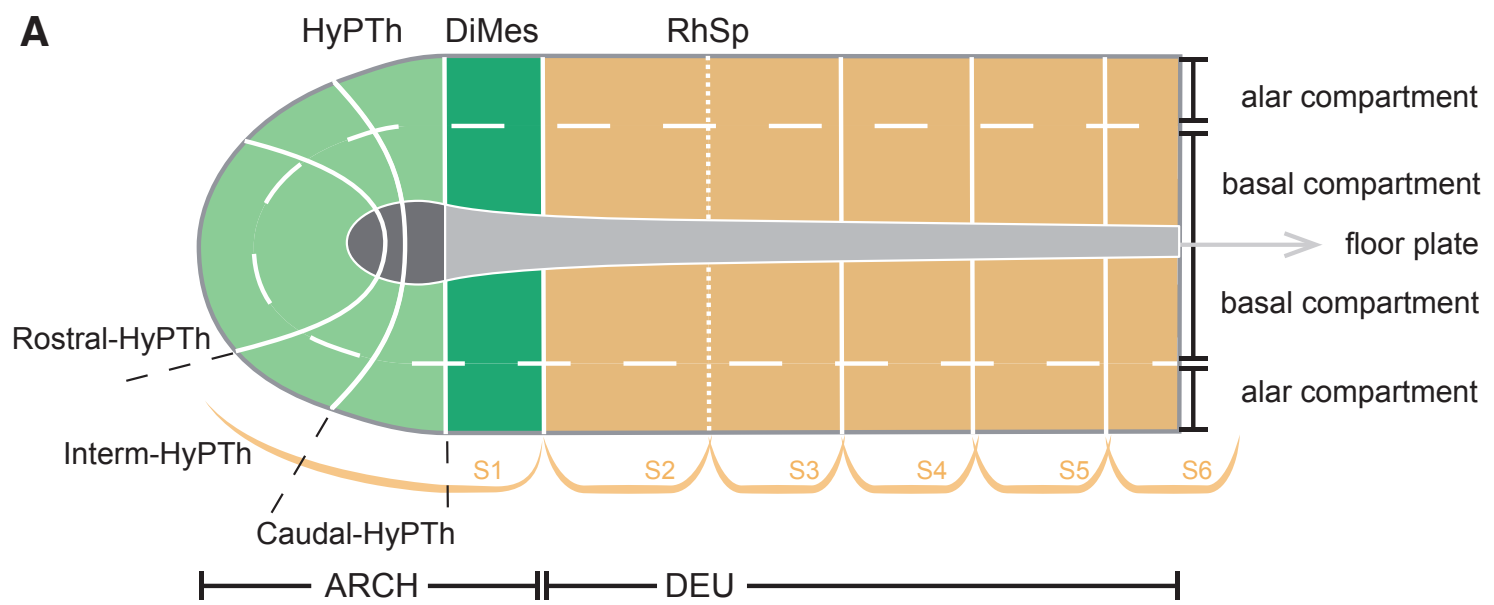

B
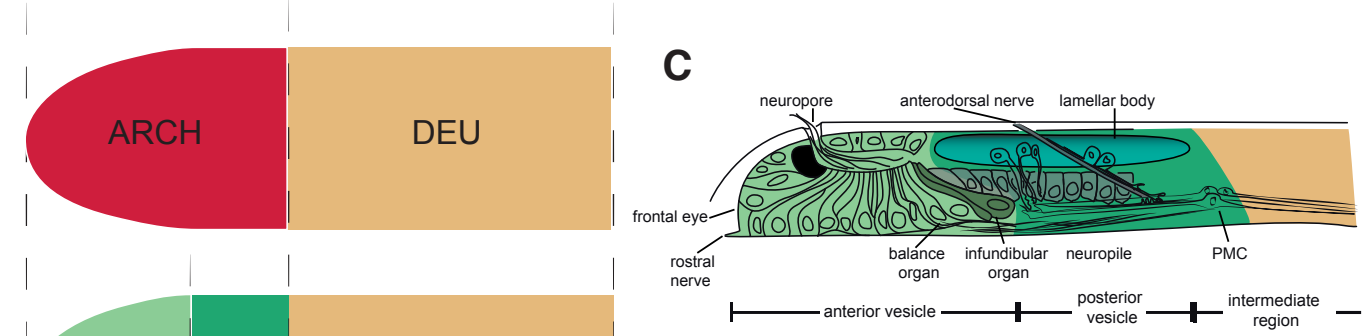

B'
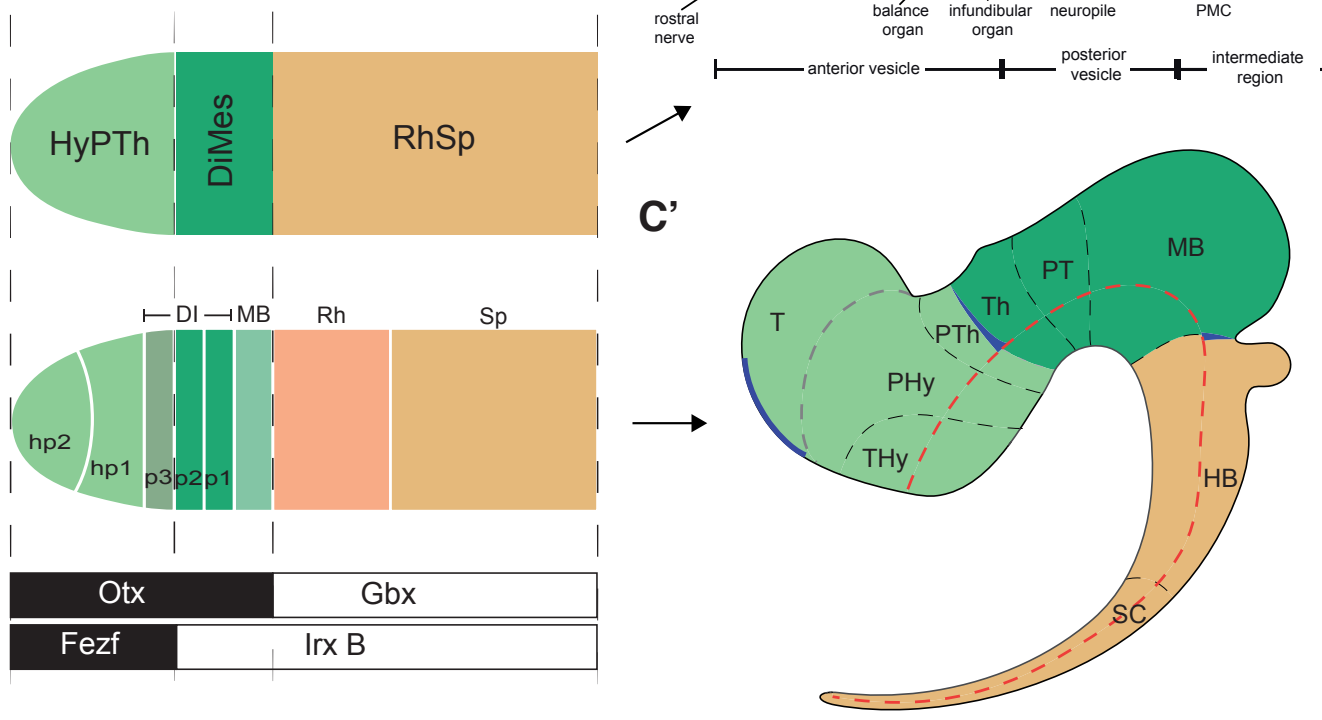

B”

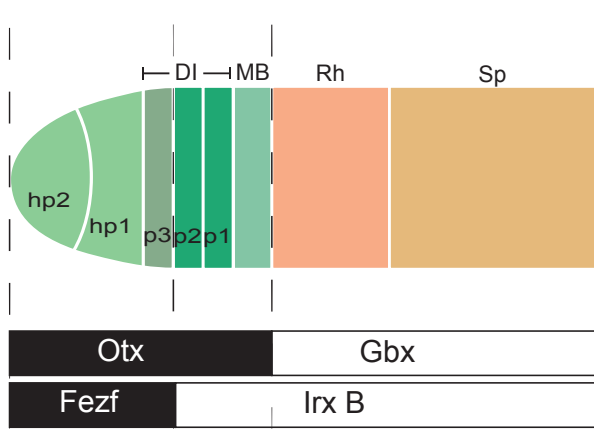

Fig. 3. Ontogenetic correspondences and proposed homologies between cephalochordates and vertebrates CNS. (A) Summary of all identified anteroposterior and dorsoventral partitions of the neural plate of amphioxus, dorsal-view scheme, anterior is to the left. Hypothalamo-prethalamic primordium (HyPTh), DiMesencephalic primordium (DiMEs), Rhombencephalo-Spinal primordium (RhSp). S1-S6 indicates the relative position of the six most anterior somites. (B-B") Topological comparison of major molecular subdivisions between an ancestor with a bipartite brain (B), cephalochordates $\left(B^{\prime}\right)$ and vertebrates $\left(B^{\prime \prime}\right)$. Archencephalic prototagma $(A R C H)$, deuteroencephalic prototagma (DEU). The amphioxus DiMEs seems to be homologous to the thalamus (p2), pretectecum (p1) and midbrain (MB), whereas the diencephalon (DI) is neither an ontogenetic nor an evolutionary unit, as the prethalamus (p3) is derived from a vertebrate-specific subdivision of the HyPTh. Gene expression domains of relevant genes (Otx, Gbx, Fezf and IrxB) that mark the three main subdivisions of the chordate brain are indicated below. (C-C') Correspondence of the three main subdivisions (colour coded) of the neural plate to the larval stages of amphioxus $(C)$ and a representative neural tube of vertebrates $\left(C^{\prime}\right)$. Blue spikes indicate the secondary organizers IsO (left) and ZLI (right) in C'. Primary motor center (PMC), hindbrain (HB). Adapted from Albuixech-Crespo et al., (2017). 
in vertebrate and amphioxus neural regionalization is abundant. Very recently, some of us with our collaborators (Albuixech-Crespo et al., 2017) mapped the expression of 48 genes whose orthologs in vertebrates have a well-established morphological interpretation within the prosomeric model. These mappings were done at a single developmental stage of amphioxus (7-somite neurula stage), allowing homochronic comparisons of gene expression patterns. With these data, the authors proposed a genoarchitectonic model for amphioxus consistent with the prosomeric model (Fig. 3). As previously suggested (Castro et al., 2006), this model proposes that the incipient amphioxus neural tube is molecularly divided into a rostral archencephalic (ARCH) domain and a caudal deuterencephalic (DEU) domain from very early stages, similarly to vertebrates. This division is highlighted by the abutting expression domains of Otx and Gbx. Furthermore, the amphioxus ARCH has two major subdivisions, which we termed Hypothalamo-Prethalamic primordium (HyPTh; further subdivided into Rostral-HyPTh, Interm-HyPTh and Caudal-HyPTh) and Di-Mesencephalic primordium (DiMes) (Fig. $3 \mathrm{~B}$ ), whose boundary is defined by the abutting expression of $F e z$ on the most caudal HyPTh domain (Caudal-HyPTh) with that or the Irx genes in the DiMes. In contrast, and as mentioned above, the vertebrate $A R C H$ is traditionally divided into three main regions, the secondary prosencehalon (hypothalamus plus telencephalon), the diencephalon (pretectum, thalamus and prethalamus) and the midbrain. Remarkably, considering its topological position relative to several markers as Fez and Irx, the Caudal-HyPTh may be homologous to the vertebrate prethalamus. In addition, the small amphioxus DiMes, consisting of two rows of cells along the AP axis at the mid-neurula stage, seems to be homologous to the thalamus, pretectum and midbrain all together. Therefore, the last two observations, together with multiple lines of experimental embryological evidence (Gardner and Barald, 1991; Martinez et al., 1991; Bally-Cuif et al., 1992; Bloch-Gallego et al., 1996; Vieira et al., 2005; Vue et al., 2009; Hirata, 2006), profoundly challenge textbook subdivisions of the vertebrate brain: (i) the diencephalon loses its coherence as a single entity, since it has neither evolutionary nor developmental support, and (ii) the vertebrate thalamus, pretectum and midbrain should be considered an evolutionary elaboration of an ancestral, perhaps amphioxus-like, DiMes region.

The hypothesis that the diencephalon is neither an evolutionary nor an ontogenetic primordial subdivision of the vertebrate brain was further supported by knock-out and knock-down experiments in mouse and zebrafish (Albuixech-Crespo et al., 2017). Patterning of the DiMes-like territory in vertebrates occurs under the control of the secondary organizers $\mathrm{ZLI}$ and IsO, which, despite ongoing debate, seem to be absent in amphioxus (Shimeld, 1999; Pani et al., 2012). Interfering with the vertebrate ZLI turns the thalamic region into a pretectum-like territory, ablating the IsO abolishes the midbrain and expands the pretectum territory, and a quadruple morpholino in zebrafish that alters both ZLI and IsO transforms those three DiMes regions of vertebrates (thalamus, pretectum and midbrain) into a more molecularly homogeneous structure that resembles the amphioxus DiMes region (Fig. 4). Therefore, these results suggest a close relationship between the gain or loss of secondary organizers during evolution and the origin or loss of specific partitions in the brain among the major chordate groups.

\section{Amphioxus genoarchitectonic model provides novel insights into the ontogeny of adult structures and their homology with vertebrates}

Our genoarchitectonic model of the developing amphioxus neural tube also sheds light into the ontogenetic origins of several larval and adult brain structures, and their possible evolutionary relationships with vertebrate derivatives. Ontogenetic assignments between adult, larval and embryonic structures and domains have many limitations in amphioxus. First, the lack of cell tracing data on the formation of neural derivatives hampers direct extrapolations of adult neural populations from early stages of development. Second, there is no information about the possible migration processes that the progenitor populations of the terminal derivatives of the adult neural tube experience. Third, there are no robust continuous reference landmarks. Two main references have been used in the literature to infer correspondences among
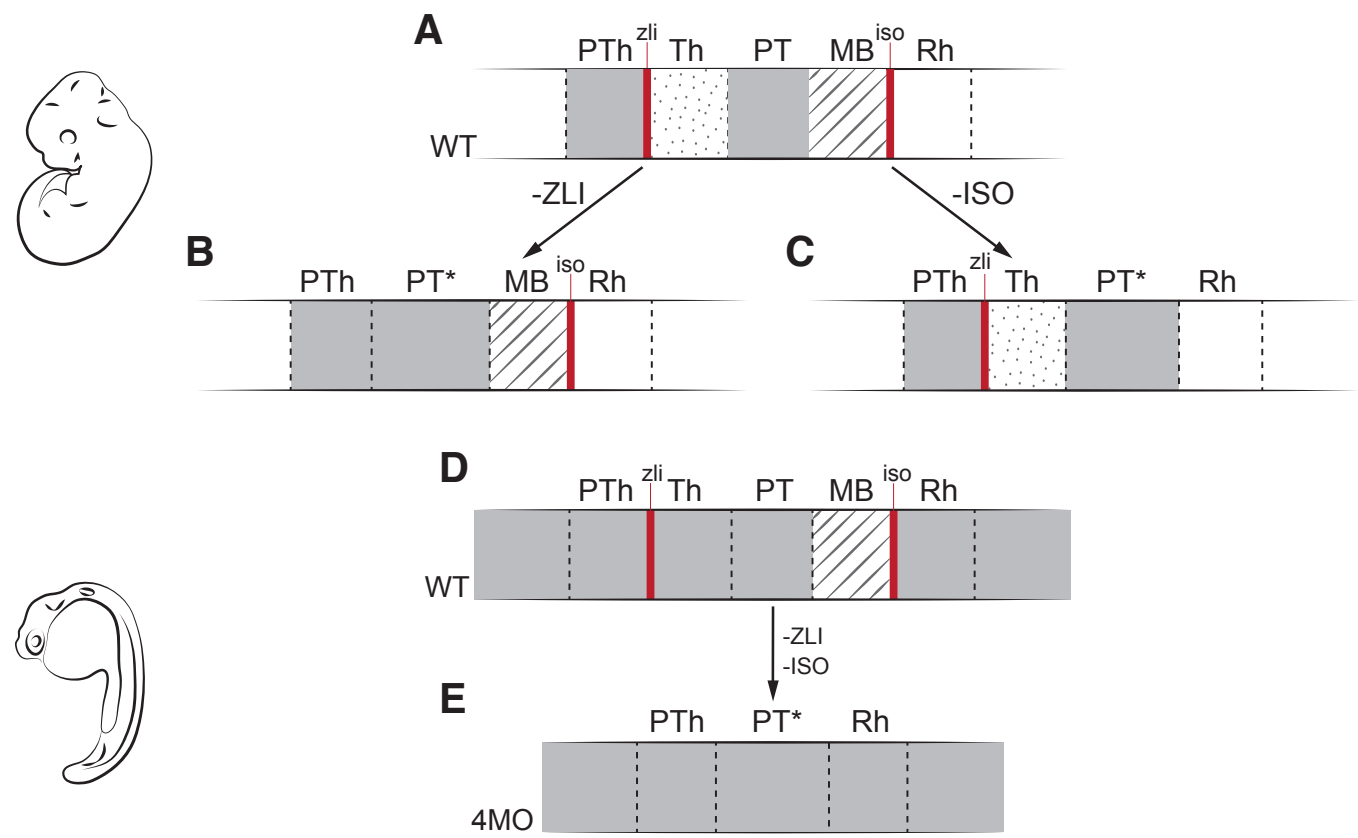

Fig. 4. Experimental disruption of vertebrate secondary organizers recapitulates the amphioxus brain. (A) Schematic representation of major neural compartments (PTh, Th, PT, MB, and $R h)$ around DiMes, delimited by the secondaryorganizers (ZLIand IsO red lines) in wild type (WT) vertebrates; solid gray indicates Pax6 expression. (B) Abrogation of the ZLI turns the thalamic region into a pretectum-like territory $\left(P T^{*}\right)$. (C) Genetic depletion of the ISO abolishes the midbrain and expands the pretectum territory $\left(P T^{*}\right)$. (D) Wild type and (E) quadruple morpholino of otx1a, otx2, eng2a, and eng2 $\mathrm{b}$ in zebrafish eliminates $\mathrm{ZLI}$ and IsO, and thus the whole DiMes loses its subdivisions and mimics the uniform amphioxus DiMes. Adapted from Albuixech-Crespo et al., (2017). 
neural structures. One is the position of these structures respect to the myomeres or somites in adults or embryos, respectively. Unfortunately, however, it has not yet been proven whether the position and the size of myomeres are fixed or permanent in relation to the neural tube, hampering ontogenetic assignments. The other one is innervation, which presents concordances with the myomeric asymmetry endorsed by the myoseptal position of the neural roots in the neural tube of the adult amphioxus. However, these are difficult to extrapolate to early embryos.

Given these caveats, extrapolations on the correspondence of the neural derivatives in the adult amphioxus with respect the progenitor territories in the neural plate stage during development must come from meticulous correlations that include information for both its topological position and the combination of gene expression patterns during neural ontogeny, always keeping in mind that gene expression patterns could be very dynamic and that they do not provide deep lineage information if considered independently. Keeping these limitations in mind, we revise here previous literature and propose some ontogenetic correspondences for important terminal derivatives of the anterior CNS of amphioxus, and discuss their implications to assign vertebrate homologies

\section{Frontal eye and visual system}

One of the most visible structures of the amphioxus neural tube is the frontal eye, which can be observed from early larval stages. The topological position of the frontal eye suggests that it arises from the most anterior part of the neural plate (Lacalli, 1996), the acroterminal domain (Fig. 3), as it occurs in vertebrates (McMahon and Bradley, 1990; Puelles et al., 2012; Puelles and Rubenstein, 2015; Albuixech-Crespo et al., 2017). The genoarchitecture of this area in the neural plate suggests its involvement in the development of this photoreceptive structure. Several genes expressed very early in amphioxus development are involved in eye structures in a wide number of bilaterians, such as $R x$, Six3/6 and $L h x 2 / 9$ (Zuber et al., 2003; Kamijyo et al., 2015; Albuixech-Crespo et al., 2017), even though the development of the amphioxus frontal eye becomes apparent only later in development by the emergence of the cells with dendrites and cilia that protrude from the neuropore and by the presence of the pigment cup. Remarkably, at larval stages, when the frontal eye is evident, the resulting cellular types that form it maintain a characteristic genoarchitecture. Both in vertebrates and cephalochordates Giand c-Opsinare expressed in photoreceptors, whereas Mitf and Pax2/5/8 appear in pigment cells (Vopalensky et al., 2012). In vertebrates, two eye regions develop as a result of the splitting of the morphogenetic eye field by the action of signals coming from the prechordal mesoderm (Zuber et al., 2003), while in amphioxus it stays as a single medial structure.

The amphioxus frontal eye innervates the neuropile through serotonergic neurons (Vopalensky et al., 2012). This neuropile develops immediately caudal to the infundibular organ, which marks the transition between the anterior vesicle and the posterior region of the cerebral vesicle. It projects to the primary motor center (PMC), located more caudally, in the region immediately posterior to the limit between the $1^{\text {st }}$ and the $2^{\text {nd }}$ myomeres (Fig. 3C). Part of this region expresses Pax4/6 in larval stages (Suzuki et al., 2014) and, topologically, it seems to correspond to the Pax4/6-positive DiMes region described in our genoarchitectonic model (Albuixech-Crespo et al., 2017). Interestingly, the frontal eye of amphioxus as well as the paired eyes of the lamprey larva project to a photoreceptor visual center that is Otx- and Pax4/6-positive, located in the most posterior region of the cerebral vesicle in amphioxus larvae, and in the caudal prosencephalon in lampreys (Suzuki et al., 2014) (Fig. 2A). In the latter study, Suzuki and colleagues suggested that the mesencephalic optic projections (which are retino-tectal, Pax6negative and Otx2-positive) are secondarily developed, specific to vertebrates, and implicated in vision image formation. In consequence, the retino-pretectal primary projections, which appear in earlier stages of lamprey larvae, would be more similar to the ancestral state in vertebrates projecting to a visual Pax6-positive center, as it occurs in amphioxus. Lacalli (1996) identified the visual center of amphioxus tracking the projections from the frontal eye through electronic microscopy, and named it tectum, as a reference of homology to the midbrain in vertebrates. However, other authors concluded that cephalochordates lack a proper homolog to the tectal region, based on the absence of expression of $D m b x$ in the amphioxus neural tube (Takahashi and Holland, 2004), which is expressed in the midbrain of vertebrates. Our genoarchitectonic model of the neural plate of amphioxus described above sheds light into the evolutionary common origin for the midbrain, thalamus and pretectum of vertebrates from a DiMes-like territory that was likely ancestrally involved in visual processing. Based on these data, it is tempting to speculate that a DiMes/pretectum-like function was ancestral, and that the origin of the midbrain as an independent unit could have been linked to the origin of the vision with image formation present in vertebrates, but not in amphioxus.

\section{Balance organ and circadian clock}

The topology and morphology of cells associated with the circadian clock and the balance organ in the adult amphioxus, which are embedded in the ventral commissure and associated to the lamellar body (a photoreceptor organ) (Figs. 1D and 3C), as well as immunoreactive to GABA, led some authors to propose its homology to the mammalian suprachiasmatic nucleus (Anadón et al., 1998; Castro and Becerra, 2015). The suprachiasmatic nucleus in vertebrates is a derivative of the alar part of the most rostral hypothalamic territory (Puelles and Rubenstein, 2015), which is Nkx2.2-positive. Also, in vertebrates, Lhx1 (also known as Lim1) is involved in the establishment and maintenance of this circadian rhythm in the suprachiasmatic nucleus (Hatori et al., 2014). In amphioxus, the genoarchitecture of the most rostral part of the neural plate is coincident, being Nkx2.2- and Lhx1/5-positive, further supporting the similarity between the two structures. However, the fact that vertebrate suprachiasmatic nucleus arises from the alar part of the hypothalamus and the amphioxus balance organ is ventral in origin casts doubts on the homology between the two derivatives.

\section{Infundibular organ}

As mentioned above, the infundibular organ is located in the most anterior part of the floor plate of the neural tube (Fig. 3C) and secretes Reissner's fiber to the central canal of the neural tube (Olsson et al., 1994; López-Avalos et al., 1997). Its functions have not been characterized in amphioxus, although it seems to be involved in axon guidance and establishment of commissures (Lehmann and Naumann, 2005). Both the amphioxus infundibular organ and the vertebrate subcommissural and flexural organs (which produce Reissner's fiber in vertebrates) are formed near developing commissures (López-Avalos et al., 1997). The subcommissural organ develops in the pretectum (p1) and is the 
primary and permanent producer of Reissner's fiber in vertebrates. Based on these observations, some authors have proposed its correspondence with the amphioxus infundibular organ (Olsson, 1955; Lichtenfeld et al., 1999). In contrast, the flexural organ is located in the most rostral floor plate of vertebrates. Therefore, given the topological position of the amphioxus infundibular organ, a probable derivative of the HyPTh, it seems more likely that, if any, the vertebrate flexural organ is a homolog of the amphioxus infundibular organ, even though the secreting action of the flexural organ is transitory (Lichtenfeld et al., 1999). However, it is also possible these chordate organs carry on analogous functions but are not homologous structures.

\section{Lamellar body}

The lamellar body (Fig. 3C) has often been proposed as a homolog of the pineal gland of vertebrates (Lacalli, 1996). Both develop from a Pax4/6-positive territory and are (at least ancestrally) photoreceptive structures. However, the amphioxus lamellar body seems to develop from the DiMes area, which does not include in its genoarchitecture the marker $R x$, essential for the development of the pineal gland in vertebrates (Ruiz and Anadón, 1991; Vopalensky et al., 2012; Rath et al., 2013). Moreover, the lamellar body is not immunoreactive to melatonin and does not produce the enzymes necessary for its synthesis (Vernadakis et al., 1998; Falcón et al., 2014). In addition, all the genes related to circadian rhythms in amphioxus are expressed in the balance organ and not in the lamellar body (Schomerus et al., 2008). Therefore, despite its similar topology, the proposed homology between the lamellar body and the pineal gland of vertebrates is not fully conclusive.

\section{Concluding remarks}

Although morphologically much simpler than vertebrates, a detailed genoarchitecture analysis of the amphioxus CNS has revealed a high level of complexity. Furthermore, it has shown many similarities to vertebrates, providing support to a common bauplan being already present in the last common ancestor of chordates. Many major AP and DV subdivisions have direct counterparts between amphioxus and vertebrates, even though they are often further subdivided in vertebrates. An example of this is the DiMes homologous region, which does not seem to be molecularly regionalized in the developing amphioxus neural tube, but is subdivided into thalamus, pretectum and midbrain in vertebrates. These comparative analyses also help to reveal cryptic ontogenetic correspondences and homologies between cephalochordate and vertebrate CNS terminal derivatives, thus shedding light into the origin and evolution of the complex vertebrate CNS and the specialized features of the amphioxus CNS. One surprising conclusion of these analyses is that the originally simple and uniform DiMes of amphioxus seems to give rise to a relatively large number of functional adult and larval structures (Fig. $3 \mathrm{C}$ ), indicating a hidden and unexplored complexity-generation potential for this region during late amphioxus CNS development.

\section{Acknowledgements}

Authors' research is funded by: the Spanish Ministry of Economy and Competitiveness; European FEDER funds (grants number BFU201457516- $P$ to JGF, SAF2016-80937-R to GM and BFU2014-55076-P to MI); the European Union Horizon 2020 research and innovation program (grant agreement No ERC-StG-LS2-637591 to MI); and by the 'Centro de Excelencia Severo Ochoa 2013-2017', SEV-2012-0208 to CRG. We would also like to acknowledge the support of the CERCA Programme I Generalitat de Catalunya. CH-B holds an FPI fellowship. The authors wish to thank José Luis Ferrán and Ignacio Maeso for comments and fruitful discussions.

\section{References}

ABOUHEIF E, AKAM M, DICKINSON W, HOLLAND PWH, MEYER A, PATEL N, RAFF R, LOUISE R, WRAY G (1997). Homology and developmental genes. Trends Genet 13: 432-433.

ACAMPORAD, AVANTAGGIATO V, TUORTO F, SIMEONE A (1997). Genetic control of brain morphogenesis through Otx gene dosage requirement. Development 124: 3639-3650.

ACEMEL R, TENA J, IRASTORZA-AZCARATE I, MARLETAZ F, GOMEZ-MARIN C, DE LA CALLE-MUSTIENES E, BERTRAND S, DIAZ S, ALDEA D, AURY JM, MANGENOT S, HOLLAND PWH, DEVOS D, MAESO I, ESCRIVA H, GOMEZSKARMETA JL (2016). A single three-dimensional chromatin compartment in amphioxus indicates a stepwise evolution of vertebrate Hox bimodal regulation. Nat Genet 48: 336-341

ALBUIXECH-CRESPOB, LÓPEZ-BLANCHL, BURGUERAD, MAESOI, SÁNCHEZARRONESL, MORENO-BRAVOJA, SOMORJAII, PASCUAL-ANAYAJ, PUELLES E, BOVOLENTA P, GARCIA-FERNÀNDEZ J, PUELLES L, IRIMIA M, FERRAN $\mathrm{JL}$ (2017). Molecular regionalization of the developing amphioxus neural tube challenges major partitions of the vertebrate brain. PLOS Biol 15: e2001573.

ANADÓN R, ADRIO F, RODRÍGUEZ-MOLDES I (1998). Distribution of GABA immunoreactivity in the central and peripheral nervous system of amphioxus (branchiostoma lanceolatum pallas). J Comp Neurol 401: 293-307.

ARENDT D, TOSCHES MA, MARLOW H (2015). From nerve net to nerve ring, nerve cord and brain - evolution of the nervous system. Nat Rev Neurosci 17: 61-72.

BALLY-CUIF L, ALVARADO-MALLART RM, DARNELL DK, WASSEF M (1992). Relationship between Wnt-1 and En-2 expression domains during early development of normal and ectopic met-mesencephalon. Development 115:999-1009.

BLAIR JE, HEDGES SB (2005). Molecular phylogeny and divergence times of deuterostome animals. Mol Biol Evol 22: 2275-2284.

BLOCH-GALLEGOE, MILLETS, ALVARADO-MALLARTRM (1996). Further observations on the susceptibility of diencephalic prosomeres to En-2 induction and on the resulting histogenetic capabilities. Mech Dev 58:51-63.

BONE Q (1960). The central nervous system in amphioxus. J Comp Neurol115:27-64.

CASTRO A, BECERRA M (2015). Neuronal Organization of the Brain in the Adult Amphioxus (Branchiostoma lanceolatum): A Study With Acetylated Tubulin Immunohistochemistry. J Comp Neurol 523: 2211-2232.

CASTRO LFC, RASMUSSEN SLK, HOLLAND PWH, HOLLAND ND, HOLLAND LZ (2006). A Gbx homeobox gene in amphioxus: Insights into ancestry of the ANTP class and evolution of the midbrain/hindbrain boundary. Dev Biol 295: 40-51.

CHI CL, MARTINEZ S, WURST W, MARTIN GR (2003). The isthmic organizer signal FGF8 is required for cell survival in the prospective midbrain and cerebellum. Development 130: 2633-2644.

COSTA O (1834). Cenni zoologici ossia descrizione sommaria delle specie nuove di animali discoperti in diverse contrade del regno nell' anno 1834. Annuario Zoologico 1834.

CROSSLEY PH, MARTINEZ S, MARTIN GR (1996). Midbrain development induced by FGF8 in the chick embryo. Nature 380: 66-68.

DEHAL P, BOORE JL (2005). Two Rounds of Whole Genome Duplication in the Ancestral Vertebrate. PLoS Biol 3: e314.

DELSUC F, BRINKMANN H, CHOURROUT D, PHILIPPE H (2006). Tunicates and not cephalochordates are the closest living relatives of vertebrates. Nature 439: 965-968.

DELSUC F, TSAGKOGEORGA G, LARTILLOT N, PHILIPPE H (2008). Additiona molecular support for the new chordate phylogeny. Genesis 46: 592-604.

DENES AS, JÉKELY G, STEINMETZ PRH, RAIBLE F, SNYMAN H, PRUD'HOMME B, FERRIER DEK, BALAVOINE G, ARENDT D, JEKELY G, STEINMETZ PRH, RAIBLE F, SNYMAN H, PRUD'HOMME B, FERRIER DEK, BALAVOINE G, ARENDT D (2007). Molecular Architecture of Annelid Nerve Cord Supports Common Origin of Nervous System Centralization in Bilateria. Cell 129: 277-288. 
FALCÓN J, COON SL, BESSEAU L, CAZAMÉA-CATALAN D, FUENTĖS M, MAGNANOU E, PAULIN C-H, BOEUF G, SAUZET S, JØRGENSEN EH, MAZAN S, WOLF YI, KOONIN E V, STEINBACH PJ, HYODO S, KLEIN DC (2014). Drastic neofunctionalization associated with evolution of the timezyme AANAT 500 Mya. Proc Natl Acad Sci USA 111: 314-319.

FERRANJL, DE OLIVEIRAED, MERCHÁNP, SANDOVALJE, SÁNCHEZ-ARRONES L, MARTÍNEZ-DE-LA-TORRE M, PUELLESL (2009). Genoarchitectonic profile of developing nuclear groups in the chicken pretectum. J Comp Neurol517: 405-451.

FERRAN JL, SÁNCHEZ-ARRONES L, BARDET SM, SANDOVAL JE, MARTÍNEZDE-LA-TORRE M, PUELLES L (2008). Early pretectal gene expression pattern shows a conserved anteroposterior tripartition in mouse and chicken. Brain Res Bull 75: 295-298.

FERRAN JL, SANCHEZ-ARRONES L, SANDOVAL JE, PUELLES L (2007). A model of early molecular regionalization in the chicken embryonic pretectum. $J$ Comp Neurol 505: 379-403.

FORCE A, LYNCH M, PICKETT FB, AMORES A, YAN Y, POSTLETHWAIT J (1999) Genetics 151: 1531-1545

GARCIA-FERNANDEZ J, BENITO-GUTIERREZ E (2009). It's a long way from amphioxus: descendants of the earliest chordate. Bioessays 31: 665-675.

GARCIA-FERNANDEZ J, HOLLAND PWH (1994). Archetypal organization of the amphioxus Hox gene cluster. Nature 370: 563-566.

GARDA AL, ECHEVARRÍA D, MARTíNEZ S (2001). Neuroepithelial co-expression of Gbx2 and Otx2 precedes Fgf8 expression in the isthmic organizer. Mech Dev 101: 111-118.

GARDNER CA, BARALD KF (1991). The cellular environment controls the expression of engrailed-like protein in the cranial neuroepithelium of quail-chick chimeric embryos. Development 113:1037-1048.

HATORI M, GILL S, MURE LS, GOULDING M, O'LEARY DD, PANDA S (2014). Lhx1 maintains synchrony among circadian oscillator neurons of the SCN. eLife: 3: e03357.

HIDALGO-SÁNCHEZ M, MILLET S, BLOCH-GALLEGO E, ALVARADO-MALLART RM (2005). Specification of the meso-isthmo-cerebellar region: The Otx2/Gbx2 boundary. Brain Res Rev 49: 134-149.

HIRATA T (2006). Zinc-finger genes Fez and Fez-like function in the establishment of diencephalon subdivisions. Development 133: 3993-4004.

HIRTH F (2010). On the origin and evolution of the tripartite brain. Brain Behav Evol 76: 3-10.

HOLLAND LZ, HOLLAND ND (2007). A revised fate map for amphioxus and the evolution of axial patterning in chordates. Integr Comp Biol 47: 360-372.

HOLLAND LZ, KENE M, WILLIAMS N a, HOLLAND ND (1997). Sequence and embryonic expression of the amphioxus engrailed gene (AmphiEn): the metameric pattern of transcription resembles that of its segment-polarity homolog in Drosophila. Development 124: 1723-1732.

HOLLAND ND, PANGANIBAN G, HENYEY EL, HOLLAND LZ (1996). Sequence and developmental expression of AmphiDII, an amphioxus Distal-less gene transcribed in the ectoderm, epidermis and nervous system: insights into evolution of craniate forebrain and neural crest. Development 122: 2911-2920.

HOLLAND PWH, HOLLAND LZ, WILLIAMS NA, HOLLAND ND (1992). An amphioxus homeobox gene: sequence conservation, spatial expression during development and insights into vertebrate evolution. Development 116: 653-661.

HOLLAND PW,GARCIA-FERNÀNDEZ J, WILLIAMS N, SIDOW A (1994). Gene duplications and the origins of vertebrate development. DevSupp/1994:125-133.

IRIMIA M, PIÑEIRO C, MAESO I, GÓMEZ-SKARMETA JL, CASARES F, GARCIAFERNÀNDEZ J, PINEIRO C, MAESO I, GOMEZ-SKARMETA JL, CASARES F, GARCIA-FERNANDEZ J, PIÑEIRO C, MAESO I, GÓMEZ-SKARMETA JL, CASARES F, GARCIA-FERNÀNDEZ J (2010). Conserved developmental expression of Fezf in chordates and Drosophila and the origin of the Zona Limitans Intrathalamica (ZLI) brain organizer. Evodevo 1: 7.

JIMENEZ-DELGADO S, PASCUAL-ANAYAJ,GARCIA-FERNÀNDEZJ (2009). Implications of duplicated cis-regulatory elements in the evolution of metazoans: the DDI model or how simplicity begets novelty. BriefFunct Genomic Proteomic 8: 266-275.

KAMIJYO A, YURA K, OGURA A (2015). Distinct evolutionary rate in the eye field transcription factors found by estimation of ancestral protein structure. Gene 555: 73-79.

KIECKER C, LUMSDEN A (2012). The Role of Organizers in Patterning the Nervous System. Annu Rev Neurosci 35: 347-367.
KOZMIK Z, HOLLAND ND, KALOUSOVA A, PACES J, SCHUBERT M, HOLLAND LZ (1999). Characterization of an amphioxus paired box gene, AmphiPax2/5/8: developmental expression patterns in optic support cells, nephridium, thyroid-like structures and pharyngeal gill slits, but not in the midbrain-hindbrain boundary region. Development 126: 1295-1304.

KUHLENBECK H (1967). The Central Nervous System of Vertebrates. Yale J Biol Med 40: 170.

LACALLI TC (1996). Frontal Eye Circuitry, Rostral Sensory Pathways and Brain Organization in Amphioxus Larvae: Evidence from 3D Reconstructions. Philos Trans R Soc B Biol Sci 351: 243-263.

LACALLI TC (2002). Sensory pathways in amphioxus larvae I. Constituent fibres of the rostral and anterodorsal nerves,their targets and evolutionary significance. Acta Zool 83: 149-166.

LACALLI TC, HOLLAND ND, WEST JE (1994). Landmarks in the anterior central nervous system of amphioxus larvae. Phil Trans $R$ Soc Lond 344: 165-185.

LEHMANN C, NAUMANN WW (2005). Axon pathfinding and the floor plate factor Reissner's substance in wildtype, cyclops and one-eyed pinhead mutants of Danio rerio. Dev Brain Res 154: 1-14.

LICHTENFELD J, VIEHWEG J, SCHÜTZENMEISTER J, NAUMANN WW (1999). Reissner's substance expressed as a transient pattern in vertebrate floor plate. Anat Embryol (Berl) 200: 161-174.

LÓPEZ-AVALOS MD, CIFUENTES M, GRONDONA JM, MIRANDA E, PÉREZ J, FERNÁNDEZ-LLEBREZ P (1997). Rostral floor plate (flexural organ) secretes glycoproteins immunologically similar to subcommissural organ glycoproteins in dogfish (Scyliorhinus canicula) embryos. Brain Res Dev Brain Res 102: 69-75.

LOWE CJ, TERASAKI M, WU M, FREEMAN JR. RM, RUNFT L, KWAN K, HAIGO S, ARONOWICZ J, LANDER E, GRUBER C, et al., (2006). Dorsoventral patterning in hemichordates: Insights into early chordate evolution. PLOS Biol4: 1603-1619.

LOWE CJ, WU M, SALIC A, EVANS L, LANDER E, STANGE-THOMANN N, GRUBER CE, GERHART J, KIRSCHNER M (2003). Anteroposterior patterning in hemichordates and the origins of the chordate nervous system. Cell113: 853-865.

MARTINEZ S, WASSEF M, ALVARADO-MALLART RM (1991). Induction of a mesencephalic phenotype in the 2-day-old chick prosencephalon is preceded by the early expression of the homeobox gene en. Neuron 6: 971-981.

MCMAHONAP, BRADLEYA (1990). The Wnt-1 (int-1) proto-oncogene is required for development of a large region of the mouse brain. Cell 62: 1073-1085.

MEDINA L, BUPESH M, ABELLÁN A (2011). Contribution of genoarchitecture to understanding forebrain evolution and development, with particular emphasis on the amygdala. Brain Behav Evol 78: 216-236.

MERCHÁN P, BARDET SM, PUELLES L, FERRAN JL (2011). Comparison of Pretectal Genoarchitectonic Pattern between Quail and Chicken Embryos. Front Neuroanat 5: 23

MORONA R, FERRAN JL, PUELLES L, GONZALEZ A (2017). Gene expression analysis of developing cell groups in the pretectal region of Xenopus laevis. JComp Neurol 519: 1-38.

MORONA R, FERRAN JL, PUELLES L, GONZÁLEZ A (2011). Embryonic genoarchitecture of the pretectum in Xenopus laevis: A conserved pattern in tetrapods. J Comp Neurol 519: 1024-1050.

OHNO S (1970). Evolution by gene duplication. Springer-Verlag, New York.

OLSSON R (1955). Structure and Development of Reissner's Fibre in the caudal end of amphioxus and some lower vertebrates Acta Zool 36: 167-198.

OLSSON R, YULIS R, RODRIGUEZ EM (1994). Cell \& Tissue The infundibular organ of the lancelet (Branchiostoma lanceolatum, Acrania): an immunocytochemical study. Cell Tissue Res. 277: 107-114.

OSORIO J, MAZAN S, RETAUX S (2005). Organisation of the lamprey (Lampetra fluviatilis) embryonic brain: insights from LIM-homeodomain, Pax and hedgehog genes. Dev Biol 288: 100-112.

OWEN R (1848). On the archetype and homologies of the vertebrate skeleton. (Ed. John van Voorst).

PALLAS P (1774). Spicilegia zoologica: quibus novae imprimis et obscurae animalium species iconibus, descriptionibus atque commentariis illustrantur. Berolini. Fasciculus 10: 1-411.

PANI AM, MULLARKEY EE, ARONOWICZ J, ASSIMACOPOULOS S, GROVE EA, LOWE CJ (2012). Ancient deuterostome origins of vertebrate brain signalling centres. Nature 483: 289-294. 
PUELLESL(1995). Asegmental morphological paradigm for understanding vertebrate forebrains. Brain Behav Evol 46: 319-337.

PUELLES L (2010). Forebrain Development: Prosomere Model. Encycl Neurosci: 315-319.

PUELLES L, FERRAN JL (2012). Concept of neural genoarchitecture and its genomic fundament. Front Neuroanat 6: 47.

PUELLESL, MARTINEZ-DE-LA-TORRE M, BARDETSM, RUBENSTEINJLR (2012). The mouse neurvous system. In Hypothalamus (eds Watson C, Paxinos G, Puelles L). Academic Press/Elsevier, London, San Diego, pp. 221-312.

PUELLES L, RUBENSTEIN JL (1993). Expression patterns of homeobox and other putative regulatory genes in the embryonic mouse forebrain suggest a neuromeric organization. Trends Neurosci 16: 472-479.

PUELLES L, RUBENSTEIN JLR (2015). A new scenario of hypothalamic organization: rationale of new hypotheses introduced in the updated prosomeric model. Front Neuroanat 9: 27.

PUTNAM N, BUTTS T, FERRIER D, FURLONG R, HELLSTEN U, KAWASHIMA T, ROBINSON-RECHAVI M, SHOGUCHI E, TERRY A, YU JR-KAI, BENITOGUTIERREZ E, DUBCHAK I, GARCIA-FERNANDEZ J, GIBSON-BROWN J, GRIGORIEV I, HORTON A, DE JONG P, JURKA J, KAPITONOV V, KOHARA Y, KUROKI Y, LINDQUIST E, LUCAS S, OSOEGAWA K, PENNACCHIO L, SALAMOV A, SATOU Y, SAUKA-SPENGLER T, SCHMUTZ J, SHIN-I T, TOYODAA, BRONNER-FRASER M, FUJIYAMA A, HOLLAND LZ, HOLLAND PWH, SATOH $\mathrm{N}, \mathrm{ROKHSARD}$ (2008). The amphioxus genome and the evolution of the chordate karyotype. Nature 453: 1064-1071.

RATH MF, ROHDE K, KLEIN DC, MØLLER M (2013). Homeobox genes in the rodent pineal gland: Roles in development and phenotype maintenance. Neurochem Res 38: 1100-1112.

RODRÍGUEZ-SEGUEL E, ALARCÓN P, GÓMEZ-SKARMETAJL (2009). The Xenopus Irx genes are essential for neural patterning and define the border between prethalamus and thalamus through mutual antagonism with the anterior repressors Fezf and Arx. Dev Biol 329: 258-268.

RUIZS, ANADÓN R (1991). The fine structure of lamellate cells on the brain of amphioxus (Branchiostoma lanceolatum, Cephalochordata). Cell Tissue Res: 597-600.

SÁNCHEZ-ARRONES L, FERRÁN JL, RODRÍGUEZ-GALLARDO L, PUELLES L (2009). Incipient forebrain boundaries traced by differential gene expression and fate mapping in the chick neural plate. Dev Biol 335: 43-65.

SCHOMERUS C, KORF H-W, LAEDTKE E, MORET F, ZHANG Q, WICHT H (2008). Nocturnal behavior and rhythmic period gene expression in a lancelet, Branchiostoma lanceolatum. J Biol Rhythms 23: 170-181.

SHIMELD SM (1999). The evolution of the hedgehog gene family in chordates: insights from amphioxus hedgehog. Dev Genes Evol 209: 40-47.
STEINMETZ PRH, KOSTYUCHENKO RP, FISCHER A, ARENDT D (2011). The segmental pattern of otx, gbx, and Hox genes in the annelid Platynereis dumerilii. Evol Dev 13: 72-79.

SUZUKIDG, MURAKAMIY, ESCRIVAH, WADAH (2014). Acomparative examination of neural circuit and brain patterning between the lamprey and amphioxus reveals the evolutionary origin of the vertebrate visual center. J Comp Neurol 0: 1-11.

TAKAHASHI T, HOLLAND PWH (2004). Amphioxus and ascidian Dmbx homeobox genes give clues to the vertebrate origins of midbrain development. Development 131: 3285-3294.

TSCHOPP P, TABIN C. (2017). Deep homology in the age of next-generation sequencing. Philos Trans R Soc Lond B Biol Sci 372: 20150475.

VERNADAKIS a J, BEMIS WE, BITTMAN EL (1998). Localization and partial characterization of melatonin receptors in amphioxus, hagfish, lamprey, and skate. Gen Comp Endocrinol 110: 67-78.

VIEIRAC, GARDAAL, SHIMAMURAK, MARTINEZS (2005). Thalamic development induced by Shh in the chick embryo. Dev Biol 284: 351-363.

VIEIRAC, POMBEROA, GARCÍA-LOPEZR, GIMENOL, ECHEVARRIAD, MARTÍNEZ $S$ (2010). Molecular mechanisms controlling brain development: An overview of neuroepithelial secondary organizers. Int J Dev Biol 54: 7-20.

VOPALENSKY P, PERGNER J, LIEGERTOVAM, BENITO-GUTIERREZE, ARENDT D, KOZMIK Z (2012). Molecular analysis of the amphioxus frontal eye unravels the evolutionary origin of the retina and pigment cells of the vertebrate eye. Proc Natl Acad Sci USA 109: 15383-15388.

VUE TY, BLUSKE K, ALISHAHI A, YANG LL, KOYANO-NAKAGAWA N, NOVITCH $B$, et al.,2009). Sonic hedgehog signaling controls thalamic progenitor identity and nuclei specification in mice. JNeurosci 29: 4484-4497.

WICHT H, LACALLI TC (2005). The nervous system of amphioxus: structure, development, and evolutionary significance. Can J Zool 83: 122-150.

WICHT H, LAEDTKE E, KORF HW, SCHOMERUS C (2010). Spatial and tempora expression patterns of Bmal delineate a circadian clock in the nervous system of Branchiostoma lanceolatum. J Comp Neurol 518: 1837-1846.

WRAY G, ABOUHEIF E (1998). When is homology not homology? Curr Opin Genet Dev 8: 675-680.

YAO Y, MINOR PJ, ZHAO Y-T, JEONG Y, PANI AM, KING AN, SYMMONS O, GAN L, CARDOSO W V, SPITZ F, LOWE CJ, EPSTEIN DJ (2016). Cis-regulatory architecture of a brain signaling center predates the origin of chordates. Nat Genet. 48: 575-580.

ZUBER ME, GESTRI G, VICZIAN AS, BARSACCHI G, HARRIS W a (2003). Specification of the vertebrate eye by a network of eye field transcription factors. Development 130: 5155-5167. 


\section{Further Related Reading, published previously in the Int. J. Dev. Biol.}

From the American to the European amphioxus: towards experimental Evo-Devo at the origin of chordates

Jordi Garcia-Fernàndez, Senda Jiménez-Delgado, Juan Pascual-Anaya, Ignacio Maeso, Manuel Irimia, Carolina Minguillón, Èlia BenitoGutiérrez, Josep Gardenyes, Stéphanie Bertrand and Salvatore D’Aniello

Int. J. Dev. Biol. (2009) 53: 1359-1366

https://doi.org/10.1387/ijdb.072436jg

Peter Holland, homeobox genes and the developmental basis of animal diversity

Sebastian M. Shimeld

Int. J. Dev. Biol. (2008) 52: 3-7

https://doi.org/10.1387/ijdb.072394ss

Evo-Devo: the long and winding road.

Jaume Baguñà and Jordi Garcia-Fernàndez

Int. J. Dev. Biol. (2003) 47: 705-713

Cell morphology in amphioxus nerve cord may reflect the time course of cell differentiation T C Lacalli

Int. J. Dev. Biol. (2000) 44: 903-906

http://www.intjdevbiol.com/web/paper/11206331

Embryonic development of heads, skeletons and amphioxus: Edwin S. Goodrich revisited P W Holland

Int. J. Dev. Biol. (2000) 44: 29-34

http://www.intjdevbiol.com/web/paper/10761843

Amphioxus Hox genes: insights into evolution and development

$\mathrm{J}$ Garcia-Fernàndez and $\mathrm{P}$ W Holland

Int. J. Dev. Biol. (1996) 40: S71-S72

http://www.intjdevbiol.com/web/paper/9087701

5 yr ISI Impact Factor $(2013)=2.879$
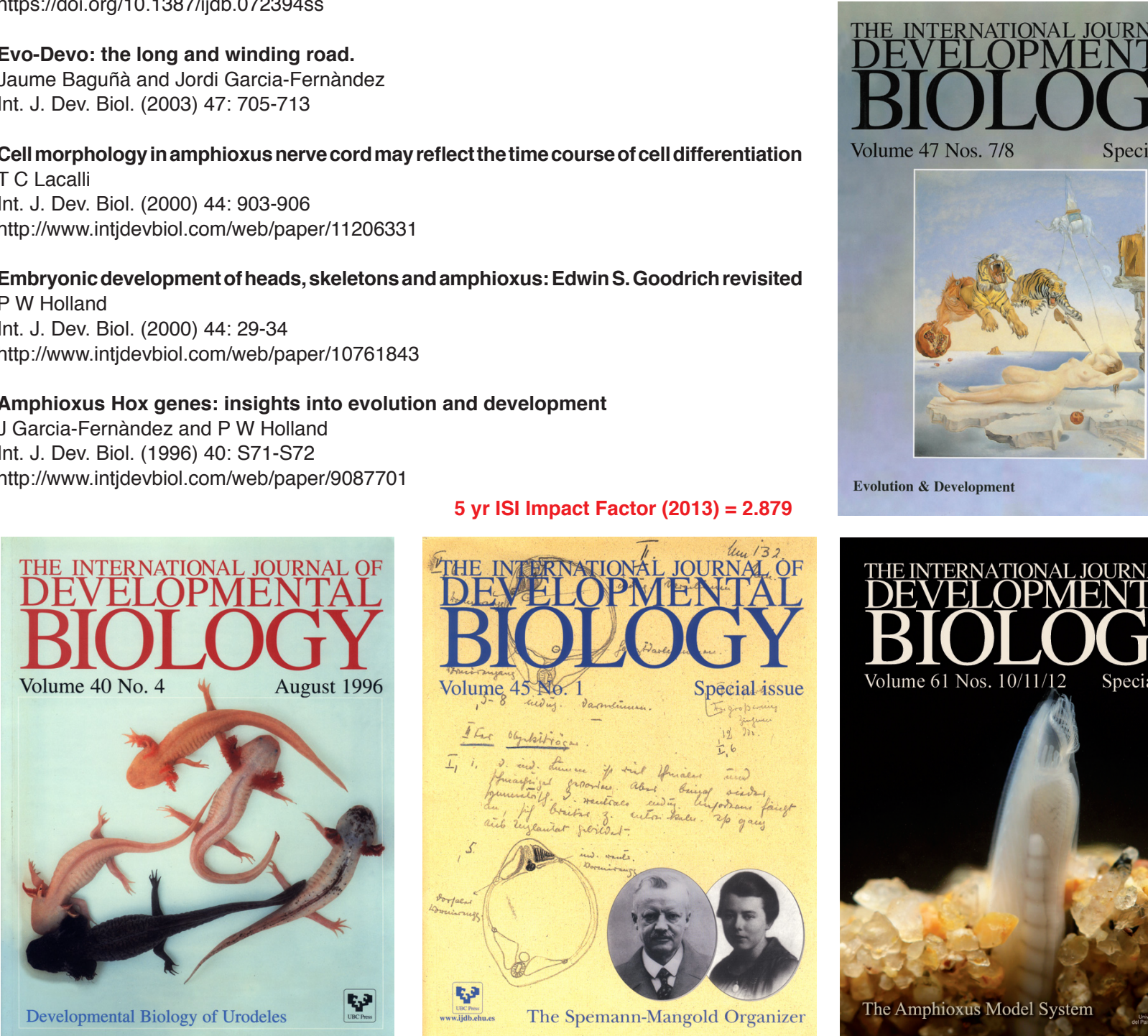

Evolution \& Development
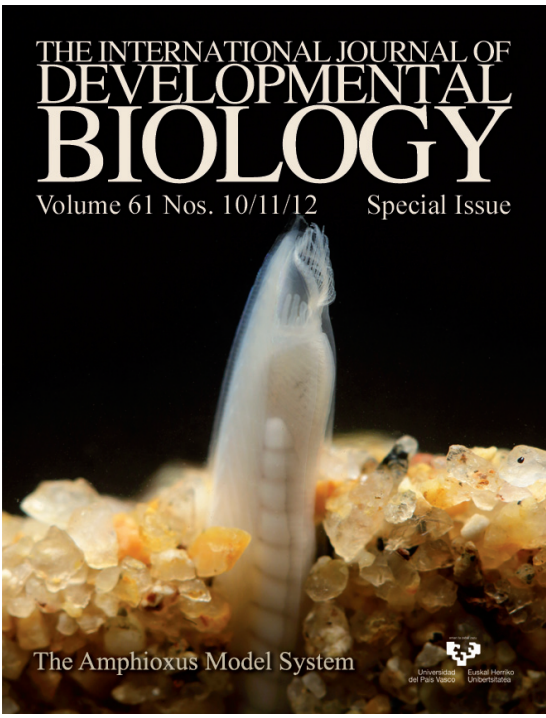